\title{
Armia chorwacka w systemie obrony państwa (od powstania do stanu obecnego) Zarys problemu
}

Wraz z proklamowaniem niepodległej Republiki Chorwacji rozpoczęto formować instytucje i jednostki, które miały bronić nowe państwo bałkańskie. Począwszy od 1991 r., wojska chorwackie, organizowane w oparciu o postjugosłowiański system Obrony Terytorialnej, przyjęły na siebie główny obowiązek utrwalenia niepodległości. Działania militarne, zakończone powodzeniem w 1995 r., przyniosły kres ponadczteroletniemu krwawemu konfliktowi i jednocześnie stały się początkiem tworzenia systemu obronnego republiki chorwackiej. Wiązało się to z pytaniem, które nurtowało tamtejszee elity od dłuższego czasu: Jak będzie wyglądała polityka bezpieczeństwa i system obronny państwa w warunkach podaytońskiego porządku?

Dla kolejnych rządów stało się oczywiste, że jedyną drogą do zapewnienia bezpieczeństwa Chorwatom jest ścisłe zwiazanie ich kraju ze strukturami północnoatlantyckimi i unijnymi. Droga ta została poprzedzona długim procesem transformacji sił zbrojnych, które musiały dostosować się do wymogów NATO. Reformy i prace nad ich wzmocnieniem trwają nadal, jednak już dzisiaj można powiedzieć, że Chorwaci, borykajacy się z licznymi problemami ekonomicznymi, stworzyli armię niewielką liczebnie, lecz dobrze wyszkoloną i wyposażona. 
Niniejszy artykuł jest zarysem obrazu transformacji chorwackich sił zbrojnych - od okresu tzw. wojny wyzwoleńczej, poprzez reformy przed wejściem do NATO, aż po obecny stan. Zwrócono w nim uwagę na kształtowanie się polityki bezpieczeństwa i tworzenie strategii obrony oraz planowania wojskowego w ciagu ostatnich 20 lat.

\section{W wojnie o niepodległość}

Siły Zbrojne Republiki Chorwacji (Oružane snage Republike Hrvatske, OS RH) wywodzą się z powstałej w $1991 \mathrm{r}$. Gwardii Narodowej ${ }^{1}$ (Zbor narodne garde, ZNG) powołanej do życia dekretem prezydenta Franjo Tuđmana². Siły paramilitarne, tworzące ZNG, stanowić miały podstawy formującej się armii chorwackiej i były przeznaczone do ochrony oraz obrony suwerenności i integralności konstytuującej się Chorwacji jako niezależnego podmiotu stosunków międzynarodowych. Zostały podporządkowane republikańskiemu Ministerstwu Spraw Wewnętrznych. Rząd chorwacki nie mógł bowiem utworzyć odrębnych sił zbrojnych, ponieważ Republika Chorwacji formalnie stanowiła część składowa państwa związkowego, czyli Socjalistycznej Federacyjnej Republiki Jugosławii (SFRJ), której siła zbrojną była Jugosłowiańska Armia Ludowa (JNA). Powstanie ZNG to też odpowiedź strony chorwackiej na przeprowadzona przez władze federalne operację rozbrojenia jednostek republikańskiej Obrony Terytorialnej

${ }^{1}$ N. Thomas, K. Mikulan, The Yugoslav Wars (1). Slovenia and Croatia 1991-95, Oxford 2006, s. 21.

${ }^{2}$ R.L. Tarnstrom, Balkan Battles. Turkey, Greece, Albania, Bulgaria, Yugoslavia, Romania, Lindsborg 1998, s. 543; Balkan Battlegrounds: A Military History of the Yugoslav Conflict, 1991-1995, vol. I, Washington 2002, s. 86 . 
(TO) i zmagazynowanie broni oraz wyposażenia jednostek chorwackiej TO w składach JNA. Miało to zapobiec, zdaniem przywódców federacji, narastającej fali napięcia i konfrontacji między chorwackimi Serbami i Chorwatami. Kroki podjęte przez władze federalne nie przyniosły pożądanych efektów, a wręcz przeciwnie - doszło do dalszego zaostrzenia sytuacji. Działania przywódców SFRJ zostały odczytane w Chorwacji jako próba wywarcia presji na władze republikańskie, ostrzeżenie oraz groźba. Po doświadczeniach wojny dziesięciodniowej w Słowenii Chorwaci wiedzieli, że władze federalne, dysponując znacznym potencjałem militarnym, jakim była JNA, nie są niepokonane. Determinacja przywódców Chorwacji oraz większości jej społeczeństwa została ukierunkowana na odzyskanie niepodległości i niezależności. ZNG formalnie przekształcono 3 listopada 1991 r. w Siły Zbrojne Republiki Chorwacji ${ }^{3}$. Ale jeszcze przez pewien okres obie formacje współistniały obok siebie. 21 września ustanowiony został Sztab Główny (Glavni stožer, GS) ${ }^{4}$, który zastapił Dowództwo ZNG. Do połowy sierpnia Chorwatom udało się utworzyć cztery ochotnicze brygady i szereg mniejszych oddziałów i pododdziałów. Zorganizowano sześć stref operacyjnych (Operativna zona, $\mathrm{OZ})^{5}$ oraz rozpoczęto tworzenie zalążków sił powietrznych i marynarki wojennej. Ogółem - do czasu restrukturyzacji wojsk chorwackich - ich siły liczyły ponad 60 tys. żołnierzy.

${ }^{3}$ Właściwie w Wojsko Chorwackie (Hrvatske vojske, HV).

${ }^{4}$ Oružane snage Republike Hrvatske. Glavni Stožer - Općenito, http:// www.osrh.hr/prikaz_hr.asp?g]o@=775\&Uvf]=4 (dostęp 21 III 2013).

5 I OZ „Osijek”, II OZ „Bjelovar”, III OZ „Zagreb”, IV OZ „Karlovac”, V OZ „Rijeka” i VI OZ „Split”, Informator o państwach b. Jugostawii $i$ ich siłach zbrojnych, Warszawa 1993, s. 4-7. Według innych danych we wrześniu 1991 r. sformowano pięć okręów armijnych, N. Erik, The Croatian Guards brigades, „Jane's Intelligence Review” 1995, vol. 7, no. 10, s. 438. 
Należy zaznaczyć, że w tym samym czasie sformowano jeszcze oddziały paramilitarne, które wzięły udział w wojnie o niepodległość. Politycy skrajnie prawicowej partii (Chorwackiej Partii Prawa) powołali do życia Chorwackie Siły Obronne (Hrvatske obrambene snage, HOS), natomiast w Hercegowinie utworzono Chorwacką Radę Obrony (Hrvatsko vijeće obrane, HVO). Siły zbrojne Chorwacji w późniejszym okresie wojny wchłonęły oddziały obu tych formacji. Wraz z narastaniem kryzysu rozbudowywano jednostki wojskowe. Brak uzbrojenia i wyposażenia uniemożliwił władzom chorwackim szybkie powołanie do życia sił zdolnych do zabezpieczenie integralności republiki, zwłaszcza że władze federalne, po nieudanej operacji w Słowenii, nie zamierzały pozwolić Chorwacji na secesję.

Do pierwszych walk pomiędzy Serbami i Chorwatami doszło już wczesną wiosną 1991 r., jednak konflikt rozgorzał ze zwiększoną siła po ogłoszeniu przez Chorwację niepodległości (25 czerwca 1991 r.). Serbowie chorwaccy, wsparci przez jednostki JNA, wypowiedzieli posłuszeństwo władzom nowo powstałego kraju i rozpoczęli działania militarne na obszarze praktycznie całego terytorium Chorwacji. Serbom, w krótkim czasie, udało się opanować ponad 30\% państwa. Od końca września $1991 \mathrm{r}$. walki w Chorwacji osiagnęły poziom konfliktu „w pełni”. Wydarzenia, rozgrywające się na Półwyspie Bałkańskim, zaniepokoiły Zachód. W wyniku mediacji doprowadzono do czasowego przerwania ognia. Sporem zajęła się także Rada Bezpieczeństwa ONZ. 25 września 1991 r. wprowadzone zostało embargo na sprzedaż broni do Jugosławii. Akt ten nie miał jednak większego wpływu na zahamowanie eskalacji konfliktu.

Pod koniec grudnia 1991 r. politykom zachodnioeuropejskim i negocjatorom ONZ udało się ponownie doprowadzić do czasowego przerwania ognia. Okres ten został spożytkowany przez Chorwatów na restrukturyzację sił zbrojnych, 
co jednak tylko nieznacznie wpłynęło na ich możliwości walki. Brak środków bojowych, wsparcia oraz doświadczenia młodych sił zbrojnych nie pozwoliły Chorwatom na zakończenie zmagań militarnych powodzeniem. Wkrótce ustały konflikty zbrojne na obszarze republiki. Na taki stan rzeczy miało też wpływ sprowadzenie sił ochronnych ONZ (UNPROFOR).

Od 1993 r. Chorwaci rozpoczęli przygotowania do szeroko zakrojonej reformy swoich sił zbrojnych. Zlikwidowano strefy operacyjne, wprowadzając $w$ ich miejsce okręgi korpusów, utworzono trzon sił uderzeniowych w składzie kilku zawodowych i mobilnych brygad, przekształcono Obronę Terytorialną w siły rezerwowe (tzw. Domobranstvo), jednocześnie likwidując dotychczasowe brygady TO. W ich miejsce powstały pułki (pukovine) ${ }^{6}$. Ponadto w trakcie konfliktu w Bośni i Hercegowinie Chorwaci podpisali porozumienie z muzułmańskimi władzami BiH, tworząc pod auspicjami USA wspólny sojusz skierowany przeciwko Serbom - chorwackim i bośniackim. Alians ten zaowocował dostawami broni i uzbrojenia z Zachodu (pomimo embarga ONZ). Rząd chorwacki podpisał także umowę z prywatnymi firmami (ze Stanów Zjednoczonych), które miały zając się szkoleniem, planowaniem i reorganizacją armii Republiki Chorwacji ${ }^{7}$. Kilkunastomiesięczne działania amerykańskich doradców przyniosły pożądany efekt w postaci

${ }^{6}$ N. Thomas, K. Mikulan, op. cit., s. 24-25.

${ }^{7}$ Firma, która miała przygotować armię chorwacką do walki z Serbami, była Military Professional Resources Inc. (MPRI). Specjaliści (byli żołnierze i oficerowie armii Stanów Zjednoczonych) zajęli się reorganizacja, planowaniem i szkoleniem sił zbrojnych Chorwacji. Faktycznie od połowy 1994 r. udało im się przygotować wojsko chorwackie do przeprowadzenia dwóch operacji, które doprowadziły do odzyskania terytorium kontrolowanego przez Serbów. Wartość kontraktu wyniosła 75 mln dolarów, R. Uesseler, Wojna jako ustuga. Jak prywatne firmy wojskowe niszcza demokrację, przeł. M. Kalata, Warszawa 2008, s. 94-95. 
dwóch wielkich operacji: „Błyskawica” i „Burza”, które doprowadziły do odzyskania przez Chorwację części Slawonii oraz Krajiny. Współczesne oceny chorwackich wojskowych wskazuja, że sukces OS RH z 1995 r. to przede wszystkim ich zasługa ${ }^{8}$. Nie jest to jednak do końca prawda. Gdyby nie pomoc amerykańska w sferze planowania i wyszkolenia, jak i szerokie wsparcie informacyjne oraz bojowe, Chorwatom nigdy nie udałoby się osiagnać - tak niskim kosztem - zwycięstwa. Ponadto należy pamiętać, że sukces armii chorwackiej był spowodowany brakiem reakcji Belgradu i Banja Luki. Jednak, pomimo tych czynników, należy ocenić, iż armia chorwacka z 1995 r. w niczym nie przypominała niezgranych, niedoposażonych i źle dowodzonych jednostek, które rozpoczynały wojnę w 1991 r. Nowoczesne - jak na ówczesne standardy - chorwackie wojsko, było znacznie lepiej wyposażone, wyszkolone i dowodzone. Operacje przeprowadzone po „Burzy” latem i jesienią 1995 r. były ostatnimi - dla Chorwatów - w długiej wojnie w byłej Jugosławii.

Jedną z konsekwencji zakończonej w 1995 r. wojny o niezawisłość była decyzja władz państwowych o demobilizacji sił zbrojnych i przejściu jednostek z etatu wojennego (,W') na pokojowy („P”), czyli redukcja ze 165 tys. do około 110 tys. żołnierzy - w pierwszej fazie restrukturyzacji chorwackich sił zbrojnych. Docelowo armia Republiki Chorwacji miała liczyć 35 tys. oficerów, podoficerów i szeregowych ${ }^{9}$. Przejście

${ }^{8}$ Amerykańska firma nigdy w oficjalnych wystapieniach nie przyznała się do udzielenia wsparcia wojskom chorwackim w operacji „Burza”. Jednak większość ekspertów uważa, iż bez udziału trzeciej strony Chorwaci nie przeprowadziliby sami tak skomplikowanej i jednocześnie jakby wyjętej z „natowskich podręczników” operacji wojskowej, P.W. Singer, Corporate Warriors. The Rise of Privatized Military Industry, Ithaca-London 2003, s. $125,127-131$ i nast.

${ }^{9}$ Później przyjęto, że liczba czynnych żołnierzy nie przekroczy 20 tys. 
ze stanu „W” na „P” nastapiło 12 marca 1996 r. na mocy dekretu F. Tuđmana ${ }^{10}$.

Transformacja systemu obronnego była niezbędna nie tylko dla gospodarki, ale przede wszystkim dla państwa, a zwłaszcza dla jego wizerunku na arenie międzynarodowej. Chorwacja musiała stać się wiarygodnym podmiotem sceny międzynarodowej zarówno w wymiarze regionalnym (bałkańskim), jak i europejskim. Dla rządu chorwackiego, zdominowanego przez partię Tuđmana, było oczywiste, że po okresie wojny należy wypracować takie kierunki w polityce zagranicznej i wewnętrznej, aby stać się jednym z tych krajów nowej Europy, który w bliższej lub dalszej perspektywie będzie gotowy do wejścia do struktur NATO i UE. W 1995 r. zapewne niewielu przypuszczało, że stanie się to możliwe, Chorwaci rozpoczęli długi proces reformy systemu obrony, w tym i sił zbrojnych, który trwa do dziśs.

\section{Droga do NATO}

Jednym z priorytetów polityki zagranicznej i bezpieczeństwa Chorwacji stała się akcesja do NATO. Po zakończeniu wojny kraj ten już w 1996 r. złożył wniosek o przystapienie do programu Partnerstwo dla Pokoju (PdP $)^{11} .20$ maja 2000 r.

${ }^{10}$ Odluka Predsjednika Republike Hrvatske dr. Franjo Tuđman prelaska na mirnodopski ustroj oružanih snaga s 12. ožujka 1996. godine, Ured Predsjednika Republike Hrvatske, http://www.predsjednik.hr/Zagreb12.03.1996_3 (dostęp 30 IV 2013).

${ }^{11}$ Partnerstwo dla Pokoju zostało zaprojektowane z zamiarem promowania aktywnej współpracy pomiędzy państwami, jeśli chodzi o kwestie bezpieczeństwa krajowego i regionalnego, w celu wzmocnienia ogólnej stabilności i bezpieczeństwa na kontynencie. Kraje kandydujące do udziału w PdP zapewniają przejrzystość budżetu wojskowego, tworzą demokratyczny 
chorwacki minister spraw zagranicznych podpisał we Florencji dokument ramowy PdP. Zgodnie z tym aktem, władze Republiki Chorwacji zobowiązały się do przestrzegania standardów demokratycznych, powstrzymania się od użycia siły lub groźby w stosunkach międzynarodowych, a także wyraziły gotowość do aktywnego uczestnictwa w walce $\mathrm{z}$ terroryzmem. Ten krok stanowił de facto pierwszy etap na długiej, bo trwającej prawie dziewięć lat, drodze do członkostwa w strukturach Sojuszu' ${ }^{12}$.

W maju 2002 r. Chorwacja została zaproszona do wzięcia udziału w przedsięwzięciach realizowanych w ramach Planu Działań na rzecz Członkostwa (MAP), który to przewidywał stopniowe przystosowanie jej struktur organizacyjnych i instytucjonalnych do wymogów Sojuszu. Jednym z głównych zadań było opracowanie norm i aktów prawnych, które umożliwiłyby Chorwatom wdrożenie procedur NATO. Dlatego kolejna faza prac nad członkostwem w Pakcie objęła działania nie tylko urzędników Ministerstwa Obrony Republiki Chorwacji (Ministarstvo obrane Republike Hrvatske, MO RH), lecz również Ministerstwa Spraw Zagranicznych, ministrów finansów, spraw wewnętrznych, urzędy prezydenta i premiera republiki. Chorwacja musiała spełnić szereg wymogów. Przede wszystkim potrzebna była gruntowna reforma nie tylko sił zbrojnych, lecz całego systemu bezpieczeństwa narodowego. Dlatego też, zgodnie ze zobowiązaniami, rząd Chorwacji przyją w październiku 2002 r. Roczny Narodowy Program

system kontroli sił zbrojnych, dostosowuja swoje przepisy do europejskich norm prawnych. Ponadto restrukturyzują siły zbrojne i wzmacniają współprace wojskowa z NATO. Aktywne uczestnictwo w Partnerstwie dla Pokoju stanowi pierwszy krok w kierunku pełnego członkostwa w Sojuszu.

${ }^{12}$ I. Šestić, Hrvatska na putu u NATO, „Hrvatski vojnik” 2005, br. 65-66, http://www.hrvatski-vojnik.hr/hrvatski-vojnik/065-662005/nato.asp (dostęp 30 IV 2013). 
2002-2003, w którym ustanowiono cele i opracowano metodykę ich realizacji. Zdecydowano się na jak najszybsze przyjęcie pakietu legislacyjnego w dziedzinie obronności i bezpieczeństwa państwa, zgodnego ze standardami NATO. Chorwacja zintensyfikowała również współpracę wojskową z państwami w regionie. Przygotowała i przeprowadziła szereg wspólnych ćwiczeń wojskowych, treningów z zakresu operacji ratowniczych, poszukiwawczych oraz likwidacji skutków katastrof technicznych i klęsk żywiołowych ${ }^{13}$.

$\mathrm{Na}$ początku XXI w. bez wątpienia stała się regionalnym liderem $\mathrm{w}$ realizacji zadań na rzecz członkostwa w NATO. Pomimo znacznych trudności (przede wszystkim natury finansowej), Chorwatom udało się w krótkim czasie opracować najważniejsze dokumenty doktrynalne (Strategia Bezpieczeństwa Narodowego i Strategiczny Przegląd Obrony) oraz akty prawne (zmiany w Ustawie zasadniczej, nowa Ustawa o obronie). Zdołano też utrzymać nakłady budżetowe na obronność - na poziomie prawie $2 \%$. Do połowy pierwszej dekady XXI w. ustabilizowano te wydatki, przeznaczając więcej środków na szkolenie i wyposażenie wojsk niż na utrzymanie infrastruktury i zatrudnienie. Zmniejszono stan liczebny sił zbrojnych, zlikwidowano szereg jednostek oraz wycofano przestarzały sprzęt, stopniowo nabywając nowe systemy uzbrojenia. W tym czasie Chorwaci aktywnie uczestniczyli w operacjach pokojowych, prewencyjnych i humanitarnych ${ }^{14}$. W ramach programu MAP zrealizowano sześć cykli, które miały doprowadzić do pełnego przygotowania ich systemu obronnego do integracji ze strukturami Sojuszu ${ }^{15}$. W stosunkowo

\section{${ }^{13}$ Ibidem.}

${ }^{14}$ W 2003 r. Chorwacja wysłała do Afganistanu w ramach natowskiej misji ISAF 150-osobowy kontyngent Policji Wojskowej.

${ }^{15}$ M. Bilandžić, Hrvatska vojska u međunarodnim odnosima, „Polemos" 2008, sv. 11, br. 22, s. 24. 
krótkim czasie udało się im zrealizować wszystkie założenia Planu i tym samym w 2008 r. Chorwacja otrzymała zaproszenie do bezpośrednich negocjacji (rozmów akcesyjnych) na temat przystapienia do NATO. Protokół w tej sprawie został podpisany w Brukseli w maju 2008 r. Przewidywał on m.in. zezwolenie na zakończenie prac nad siódmym cyklem MAP już po wejściu Chorwacji do Paktu. Ratyfikacja porozumienia została sfinalizowana w kwietniu 2009 r. ${ }^{16}$ Podczas szczytu państw NATO w Strasburgu i Kehl Chorwacja została przyjęta w poczet państw-członków Sojuszu ${ }^{17}$.

Jednym z największych problemów armii chorwackiej $\mathrm{w}$ trakcie procesu dostosowawczego był (i pozostaje) brak odpowiedniej liczby dobrze przygotowanych i wyszkolonych oficerów oraz podoficerów, mogacych pełnić służbę na różnych stanowiskach w strukturach Sojuszu. W ciagu kilku lat od wstapienia Chorwacji do Paktu udało się jednak wiele uczynić, aby jej żołnierze aktywnie uczestniczyli w pracach na rzecz NATO. Początkowo obawiano się paraliżu krajowych szczebli dowódczych, po wysłaniu do struktur Sojuszu znacznej liczby oficerów i podoficerów. Okazało się to jednak bezpodstawne, ponieważ zasoby kadr kierowniczych, pomimo nie najlepszej sytuacji finansowej, były wystarczające, aby pokryć zapotrzebowanie Sojuszu i Ministerstwa Obro$n y^{18}$. Niewątpliwie pomocne okazały się projekty szkoleniowe,

${ }^{16}$ Godišnje izvješce o spremnosti obrambenog sustava, provođenju kadrovske politike i kupnom stanju u Oružanim Snagama Republike Hrvatske za 2008. godinu, s izvješćem o stanju obrambenih priprema u Republici Hrvatskoj za 2008. godinu, Zagreb 2009, s. 5.

${ }^{17}$ Chorwacja do struktur Sojuszu Północnoatlantyckiego weszła wraz z Albania.

${ }^{18} \mathrm{~K}$. Žabec, Hrvatska vojska - Od teritorijalne obrane do NATO-a, „Jutarnij list”, 29 III 2008, http://www.jutarnji.hr/hrvatska-vojska---od-teritorijalne-obrane-do-nato-a/185629/ (dostęp 29 IV 2013). 
które chorwackie wojsko realizowało w ramach PdP, kształcąc kadry w ośrodkach i akademiach w Stanach Zjednoczonych i Niemczech. Według Planu Rozwoju Sił Zbrojnych, Republika Chorwacji powinna utrzymać 8\% stanu armii, czyli 700 żołnierzy ${ }^{19}$, w stałej gotowości do użycia w działaniach misyjnych, a 40\% - do działań w każdym momencie w dowolnym miejscu w Chorwacji. Do 2010 r. Chorwaci mieli wydzielić i wyposażyć wzmocniony batalion piechoty zmechanizowanej, zgodnie z natowskimi wymogami, mogący interweniować w dowolnym miejscu na świecie. Do realizacji misji pokojowych Chorwacja zgłosiła jednostki: policji wojskowej, operacji specjalnych, jednostkę inżynieryjno-saperska, lotniczą (dwa śmigłowce) oraz pododdział obrony przed bronią masowego rażenia (OPBMAR). Do 2010 r. ponad 1,2 tys. żołnierzy i oficerów armii chorwackiej zdobyło doświadczenie w ramach różnych misji prowadzonych w najbardziej kryzysowych rejonach świata ${ }^{20}$.

Największym problemem współczesnej armii chorwackiej jest stan sprzętu (zwłaszcza ciężkiego), kończąca się żywotność niektórych środków walki i brak finansów na niezbędne zakupy. Wszystkie rodzaje wojsk pilnie potrzebuja nowych systemów uzbrojenia przeciwpancernego, przeciwlotniczego, łączności, systemów radiolokacji, samolotów bojowych i jednostek marynarki wojennej. Część zakupów zostanie zrealizowana u rodzimych dostawców. Promocja chorwackiego przemysłu zbrojeniowego - cieszącego się zasłużoną renomą - jest jednym z priorytetowych zadań wynikających z Planu Rozwoju Sił Zbrojnych. Zakup fińskiej Patrii, modernizacja czołgu M-84D - to tylko nieliczne inwestycje, jakie udało się Chorwatom przeprowadzić w ostatnich latach. Program

${ }^{19}$ Komponent misyjny osiagnął swoją gotowość do działania w $2010 \mathrm{r}$.

${ }^{20}$ Ibidem . 
rozwoju przewiduje także nacisk na intensywne szkolenie żołnierzy chorwackich przy pomocy programów symulacji pola walki. Dlatego też obiekty poligonowe mają zostać wyposażone w najnowsze symulatory, które - jak wiadomo z doświadczenia innych armii - w znacznym stopniu obniżaja koszty szkolenia.

Chorwacja, przystępując do NATO, nie posiadała praktycznie infrastruktury, która by odpowiadała wymogom Sojuszu, zarówno w odniesieniu do prowadzenia dużych ćwiczeń, jak również pozwalającej przyjać (rozwijające lub ześrodkowujące się) siły bojowe lub logistyczne Paktu. Musiała więc przygotować część swojej infrastruktury w taki sposób, aby wypełnić w razie konieczności rolę państwa-gospodarza (wsparcie państwa-gospodarza). Podczas hipotetycznego konfliktu powinna umożliwić siłom NATO ześrodkowanie i przygotowanie się do działań bojowych oraz stanowić baze materiałowo-logistyczna. Chorwacja przystąiła do przygotowania ośmiu takich obiektów: Benkovac, Vinkovci i Gašinci, Pleso, Resnik oraz porty morskie. Koszary, magazyny, bazy lotnicze i morskie zostana zmodernizowane do poziomu standardów NATO (część tych zadań już zakończono).

\section{Strategiczny Przegląd Obrony}

Począwszy od 2003 r., rozpoczęto prace nad Strategicznym Przeglądem Obronnym (SPO). Eksperci z Ministerstwa Obrony i Sztabu Generalnego Sił Zbrojnych Chorwacji musieli opracować dokument doktrynalny, niezbędny do zainicjowania zmian w armii. Chodzi o zbudowanie zdolności i możliwości, potrzebnych do wykonywania wszystkich rodzajów misji i zadań, które moga wystapić w środowisku 
międzynarodowym - współcześnie i w przyszłości ${ }^{21}$. Jednak jednym z głównych powodów opracowania SPO była konieczność reorientacji profilu armii chorwackiej w związk ze zmianami, jakie zaszły $\mathrm{w}$ świecie oraz $\mathrm{w}$ strukturach i doktrynie NATO. Przegląd miał także służyć przygotowaniu Chorwacji, a zwłaszcza jej sił zbrojnych, do wejścia do Paktu Północnoatlantyckiego i Unii Europejskiej22.

Mając uchwaloną Strategię Bezpieczeństwa Narodowego (z 2002 r.), doktrynę obronną oraz ustawy o obronie i służbie wojskowej, Chorwacja posiadała pełny zbiór dokumentów doktrynalnych, które umożliwiały jej transformację systemu obronnego tak, by stał się kompatybilny ze strukturami euroatlantyckimi. SPO obejmował zatem listę zadań, jakie stanęły zarówno przed kierownictwem sił zbrojnych, jak i sama armia, aby po kilku latach reformy można byłoby stwierdzić, że jej transformacja została zakończona powodzeniem.

Zmiany zapoczątkowane przez SPO polegały na stopniowym przejściu od krajowego mechanizmu obrony do systemu zbiorowego bezpieczeństwa i obrony. Ponadto zrezygnowano z poboru na rzecz zawodowej służby wojskowej, co miało służyć pełnej profesjonalizacji sił zbrojnych. Uzawodowienie armii oraz przejście na system obrony zbiorowej oznaczały znaczne zmniejszenie liczby żołnierzy, którzy byli w zamian lepiej wyszkoleni i wyposażeni. Jednocześnie wytyczono obszary, w których mieli się specjalizować, zaliczając do nich: żandarmerię wojskowa, służby medyczne i logistyczne oraz pododdziały OPBMAR.

Realizacja zamierzeń zapisanych w SPO przyniosła wzrost aktywności chorwackiej armii w misjach międzynarodowych,

${ }^{21}$ I. Prodan, Pričuva Oružanih snaga Republike Hrvatske, „Hrvatski vojnik" 2005, br. 67, http://www.hrvatski-vojnik.hr/hrvatski-vojnik/0672006/pricuva.asp (dostęp 1 V 2013).

${ }^{22}$ Ibidem. 
operacjach humanitarnych i prewencyjnych. Stosunkowo niewielkie komponenty wojsk chorwackich, biorace udział w misjach ONZ, UE i NATO zostały jednak zauważone, a ich sprawność działania i wyszkolenie - wysoko ocenione. Chorwatom w stosunkowo krótkim czasie udało się stworzyć nowy wizerunek sił zbrojnych, gotowych do działan oraz mających za sobą kolejny etap przemian. Założono, że po transformacji będą liczyć około 16 tys. zawodowych żołnierzy. Część jednostek miała być w gotowości do użycia w 24 godziny od otrzymania sygnału; kolejne komponenty planowano rozwinąć w ciagu pięciu dni, a pozostałe powinny były osiagnąć pełna gotowość do działania w 30 dni. Szczególny nacisk położono na wyposażenie i wyszkolenie jednostek misyjnych (lub szybkiego reagowania) ${ }^{23}$.

SPO przebudował całkowicie dotychczasowy system obronny państwa. Obok zrestrukturyzowanych sił zbrojnych i kierownictwa obrony - powołano do życia jednolita obronę cywilną jako podsystem pozamilitarny. Stała się ona niezbędnym komponentem, wspierającym siły zbrojne oraz inne podmioty systemu bezpieczeństwa narodowego, zarówno w czasie wojny, jak i pokoju (w przypadku klęski żywiołowej lub technicznej oraz innych sytuacji kryzysowych) ${ }^{24}$. Współcześnie jednak jest on już zdezaktualizowany, dlatego też Chorwaci powinni opracować nowe założenia i wytyczne dla dalszego rozwoju wojsk i systemu obrony państwa. W ostatnim czasie ich polityka wojskowa spotyka się z silna krytyką m.in. ze strony Stanów Zjednoczonych. Od powstania

${ }^{23}$ Jednostki misyjne (lub szybkiego reagowania) - to oddziały i pododdziały armii chorwackiej, które miały brać udział w misjach międzynarodowych, realizowanych w ramach ONZ, UE i NATO (Partnerstwo dla Pokoju). Po akcesji Chorwacji do struktur NATO i UE przewidziano ich wejście w skład Sił Odpowiedzi NATO (Response Force, NRF) i Grup Bojowych.

\section{${ }^{24}$ Ibidem.}


armii chorwackiej jej związki z USA, zwłaszcza ze sferami wojskowymi, były dość bliskie, o czym już wcześniej pisano w tym artykule. Wojskowa współpraca chorwacko-amerykańska spotykała się dotychczas z dobrymi i bardzo dobrymi ocenami, szczególnie ze strony urzędników i dowódców amerykańskich. Stany Zjednoczone do 2012 r. przekazały nieodpłatnie do Chorwacji sprzęt wojskowy i technologie o wartości ponad $25 \mathrm{mln}$ dolarów (systemy łączności i symulacji pola walki oraz Humvee) ${ }^{25}$. Jednak amerykańscy wojskowi i urzędnicy Departamentu Obrony wyrażają obecnie zaniepokojenie niskim poziomem finansowania szkolenia wojskowego oraz brakiem dobrze wyszkolonych rezerw. Zarzuca się też władzom chorwackim, że proces planowania obronnego jest spóźniony, odbywa się bowiem dopiero pod koniec roku kalendarzowego, a nie - jak to ma miejsce w innych krajach - kilka miesięcy wcześniej. Krytykuje się także Chorwację za to, że nie posiada dokumentów doktrynalnych, które określałyby precyzyjnie kierunki rozwoju sił zbrojnych. Amerykanie zwrócili również uwagę, iż Chorwaci nie wspominają w swoich dokumentach i strategiach, że ich państwo od 2009 r. jest członkiem NATO. Zarzucają im także brak aktualnego Strategicznego Przeglądu Obrony ${ }^{26}$.

Proces tworzenia nowej Strategii Bezpieczeństwa Narodowego został zainicjowany w 2009 r. i miał doprowadzić do uchwalenia dokumentu doktrynalnego $\mathrm{w}$ dziedzinie bezpieczeństwa państwa ${ }^{27}$. W 2010 r., pomimo dość znacznego

${ }^{25}$ Pogled izbliza: Što SAD zamjera hrvatskom obrambenom sustavu?, „DEFENDER.hr”, http://www.defender.hr/kolumne/pogled-izbliza/ pogled-izbliza-sto-sad-zamjera-hrvatskom-obrambenom-sustavu.php (dostęp 30 IV 2013).

${ }^{26}$ Przypomniano, że nawet Serbowie byli w stanie opracować SPO.

${ }^{27}$ Ostatnia Strategia Bezpieczeństwa Narodowego została przyjęta w 2002 r. Następnie dokonano szeregu korekt w jej treści. Zasadnicze 
zawansowania prac, okazało się, że przewidywany termin ich zakończenia (trzy lata) jest nie do utrzymania (w grudniu 2010 r., przed ostateczna debata, został odwołany ze stanowiska ówczesny minister obrony narodowej Chorwacji, Branko Vukelić $^{28}$ ). W następnym roku stwierdzono, że projekt Strategii wymaga korekt i uzupełnień. W 2011 r. doszło także do wielu debat i konsultacji na ten temat z różnymi organizacjami, w tym i pozarządowymi. Dopiero w styczniu 2012 r. podjęto decyzję o powołaniu 20-osobowej Komisji, która miała przygotować Strategię Bezpieczeństwa. Komisja ta, zgodnie z wcześniejszą decyzją rządu, otrzymała 49 dni na jej opracowanie $^{29}$. Warto zadać pytanie: Czy Chorwaci sa w stanie dotrzymać ustawowych terminów przygotowania tak ważnego dokumentu? Tamtejsi eksperci uważaja, iż nie jest to możliwe. Jeśli nawet dokument zostanie opracowany, to będzie on pełen sprzeczności, błędów i trzeba go poprawiać. O brakach w dokumentach doktrynalnych wspominali także specjaliści amerykańscy.

Należy przy tym podkreślić, że uwagi urzędników Departamentu Obrony USA oraz ekspertów wojskowych raczej nie powinny znaczaco wpłynać na relacje chorwacko-amerykańskie. Współpraca obu armii w ramach misji Międzynarodowych Sił Wsparcia Bezpieczeństwa (International Security Assistance Force, ISAF) układa się bowiem bardzo dobrze. Amerykańscy wojskowi wysoko oceniaja przygotowanie i profesjonalizm Chorwatów ${ }^{30}$, dlatego też rząd USA i Pentagon

zapisy pozostały jednak przestarzałe i niespójne, zarówno ze współczesną polityką wojskowa, jak i zagraniczną Chorwacji.

${ }^{28}$ Kud je zestala nova Strategija nacionalne sigurnosti?, „OBRIS. Obrana i sigurnost", http://obris.org/hrvatska/kud -je-nestala-nova-strategija-nacionalne-sigurnosti/ (dostęp 29 IV 2013).

${ }^{29}$ Ibidem.

${ }^{30}$ Pogled izbliza: $\check{S}$ to $S A D$... 
nadal będą wspierać siły zbrojne Republiki Chorwacji. Z pewnością zwiększą się nieodpłatne dostawy sprzętu i technologii wojskowej, majacce przede wszystkim służyć szkoleniu wojsk, które biora udział w działaniach misyjnych poza granicami kraju (głównie w Afganistanie) ${ }^{31}$. Jak podkreślaja chorwaccy eksperci, pomoc amerykańska jest niezwykle potrzebna, lecz brak rozwiązań prawnych, polegających m.in. na zniesieniu opłat celnych za darowiznę z USA, powoduje, że sprzęt wojskowy dociera z opóźnieniem (w budżecie Ministerstwa Obrony nie zaplanowano środków na zapłacenie cła). Ten stan rzeczy z pewnością nie poprawi kondycji sił zbrojnych i nie przyczyni się do lepszego wyszkolenia żołnierzy chorwackich.

\section{Plan rozwój sił zbrojnych w XXI w.}

Przyjęcie SPO zaowocowało powstaniem kolejnego ważnego dokumentu, jakim jest Długoterminowy plan rozwoju Sił Zbrojnych Republiki Chorwacji w latach 2006-2015, który został uchwalony przez parlament Chorwacji 7 lipca 2006 r. Zakłada on dalszą reformę chorwackiej armii. Zamierzano wprowadzić całkowicie zawodowa służbę (co ostatecznie zostało zrealizowane w 2007 r., kiedy zrezygnowano z poboru ${ }^{32}$ ) oraz zwiększyć nakłady na siły zbrojne. Ponadto postanowiono dokonać zmiany profilu szkolenia z położeniem nacisku

${ }^{31}$ Ibidem.

${ }^{32}$ Pierwsi ochotnicy (zawodowcy) rozpoczęli służbę w listopadzie 2008 r., Ukinuto obvezno služenje vojnog roka, „Nacional”, 5 X 2007, http:// www.nacional.hr/clanak/38547/ukinuto-obvezno-sluzenje-vojnog-roka (dostęp 29 IV 2013); D. Vlahović, D. Kirin, S istim ciljem i jednom željom - postati hrvatski vojnici, „Hrvatski vojnik” 2008, br. 213, http://www.hrvatski-vojnik.hr/hrvatski-vojnik/2132008/prvirocnici.asp (dostęp 29 IV 2013). 
na tworzenie lekkich sił mobilnych, mogacych w krótkim czasie wziąc udział w działaniach misyjnych poza granicami kraju. Oprócz modernizacji sił zbrojnych w planie zawarto wytyczne i zadania z zakresu rozwoju systemu obronnego państwa. Zauważono, iż podczas kolejnych faz transformacji systemu obronnego należy dążyć do osiagnięcia takich zmian, które sprzyjałyby zdolności do reagowania na zagrożenia dla bezpieczeństwa państwa. Proces ten musi pozostać otwarty dla nowych, innowacyjnych rozwiązań w zakresie doktryny, organizacji i szkolenia.

Transformacja sił zbrojnych ma skupić się na osiagnięciu odpowiedniego poziomu przygotowania struktur organizacyjnych i wyszkolenia kadr w czasie pokoju, aby były zdolne do wykonania wszystkich zadań w dynamicznie rozwijającym się środowisku bezpieczeństwa. Proces transformacji ma uwzględniać zmiany zachodzące w strukturach i strategiach NATO, UE oraz w środowisku regionalnym i globalnym. Należy dążyć do zwiększenia zdolności i możliwości wojsk chorwackich, aby były dostosowane do nowych warunków.

Głównym zadaniem Sił Zbrojnych Republiki Chorwacji ma być aktywny udział w międzynarodowym środowisku bezpieczeństwa (m.in. w międzynarodowych operacjach reagowania kryzysowego). Działania tego rodzaju będą częścią operacji sojuszniczych, zarówno w ramach NATO, jak i ONZ, UE lub innych sił koalicyjnych, zgodnie z interesami i zdolnościami Chorwacji. Należy więc podkreślić, że plan zakłada konieczność zmian legislacyjnych, aby można dostosować prawo do przepisów, zgodnie z którymi chorwaccy żołnierze będą pełnili służbę, często znajdując się (raczej zawsze) pod obcym dowództwem.

Zwrócono także uwagę na konieczność utrzymania takich zdolności bojowych, które pomogłyby armii chorwackiej aktywnie uczestniczyć w obronie terytorium państwa. Jednocześnie zaznaczono, że współcześnie Siły Zbrojne Republiki 
Chorwacji nie są w stanie samodzielnie bronić swojego kraju. Dlatego też niezbędne będzie oparcie się na natowskim systemie. Chociaż Chorwacja przeznacza niewielkie środki finansowe na obronę, to jednak powinna w miarę możliwości rozwijać własny potencjał militarny.

Według planu, należało skoncentrować się par excellence na utrzymaniu wysokiego poziomu zdolności planowania i prowadzenia sojuszniczych działań. Aby osiagnąc to, trzeba było dostosować systemy kształcenia i szkolenia operacyjno-dowódczego do poziomu wymaganego przez NATO. Kluczowym czynnikiem pozostaje zatem uzyskanie i utrzymanie przez szczeble dowódcze i bojowe sił zbrojnych Chorwacji pełnej interoperacyjności z członkami Sojuszu w działaniach we wszystkich obszarach funkcjonowania systemu obronnego państwa.

\section{Charakterystyka chorwackich sił zbrojnych}

Polityka obrony Chorwacji jest prowadzona zgodnie ze Strategią Bezpieczeństwa Narodowego, Doktryną Obronną oraz programami rządu na kolejne lata. Zasadniczym celem i priorytetem tej polityki do 2009 r. było członkostwo w NATO i UE. Droga Chorwacji do Unii wydłużyła się jednak o cztery lata i zakończyła 1 lipca 2013 r. W ten sposób główne cele, jakie założono u progu niepodległości, zostały osiagnięte.

Inne zadania, które są realizowane w ramach polityki obronnej, skupiają się głównie na transformacji i reformie systemu obronnego państwa, a przede wszystkim na reorganizacji struktur i modernizacji sił zbrojnych ${ }^{33}$. Bardzo ważnym elementem chorwackiej polityki jest kontynuowanie i rozwijanie współpracy międzynarodowej, zarówno w sferze regionalnej,

${ }^{33}$ Godišnje izvješće o spremnosti obrambenog..., s. 15. 
jak również europejskiej i globalnej. Chorwacji bardzo zależy na kreowaniu dobrosasiedzkich kontaktów z innymi krajami Półwyspu Bałkańskiego, a zwłaszcza z powstałymi po rozpadzie Jugosławii. Wiąże się to $\mathrm{z}$ aktywnym wspieraniem i wymianą doświadczeń na temat reformy systemu obronnego z takimi państwami, jak: Bośnia i Hercegowina, Czarnogóra oraz Serbia. Chociaż wzajemne stosunki z tą ostatnią uległy ociepleniu, jednak wciąż nie brak też w nich nieufności.

Dużą wagę, w ramach polityki obronnej, rząd chorwacki przykłada do aktywności na arenie międzynarodowej. Wyrazem tego było zaangażowanie $\mathrm{w}$ misjach międzynarodowych w Afganistanie, na Bliskim Wschodzie i Afryce. Zwłaszcza misja afgańska pokazała, że Chorwaci są dobrze przygotowani planistycznie, organizacyjnie i logistycznie do wykonywania zadań poza granicami kraju. Zasygnalizowało to decydentom z Zagrzebia, że przyjęte przez nich rozwiązania są skuteczne i należy je rozwijać. Sukcesem zakończyły się kilkuletnie starania o członkostwo w Sojuszu, co też świadczy o właściwym wyborze kierunków i metod transformacji systemu obronnego oraz skuteczności reform sił zbrojnych Chorwacji.

Obecnie polityka obronna będzie ukierunkowana na wzmacnianie armii, zwłaszcza na jej modernizacji i wdrożenie nowych modeli szkolenia. Przed Chorwacją stoi szereg problemów, związanych m.in. z koniecznością opracowania nowych dokumentów doktrynalnych, czyli nowej Strategii Bezpieczeństwa, Wojennej (lub Obronnej) Koncepcji Obrony Cywilnej i innych. Z pewnościa ważnym celem polityki obronnej będzie też kontynuowanie i rozwijanie aktywności misyjnej i promocji budowy środków zaufania w regionie i Europie.

Według najważniejszych aktów prawnych, włącznie z Konstytucja Republiki Chorwacji, Siły Zbrojne sa najistotniejszym komponentem systemu obronnego państwa. Głównymi dokumentami doktrynalnymi i aktami, regulujacymi 
funkcjonowanie armii chorwackiej, sa: Konstytucja z $1990 \mathrm{r}$. (z późniejszymi zmianami), Ustawa o obronie z 25 marca 2002 r. $^{34}$ (ze zmianami z 2007 r.), Ustawa o służbie w Siłach Zbrojnych Republiki Chorwacji z 25 marca 2002 r. (z późniejszymi zmianami z 2002 i 2007 r.), Strategia Bezpieczeństwa Narodowego Republiki Chorwacji z 25 marca 2002 r., Strategia Obrony Republiki Chorwacji z 25 marca 2002 r., Długoterminowy Plan Rozwoju Sił Zbrojnych Republiki Chorwacji w latach 2006-2015 z 7 lipca 2006 r., strategiczne plany Ministerstwa Obrony z lat 2013-2015, 2012-2014 i 2011-2013.

Naczelnym Dowódcą Chorwackich Sił Zbrojnych jest Prezydent Republiki Chorwacji ${ }^{35}$. W czasie pokoju kieruje nimi $\mathrm{w}$ jego imieniu minister obrony. W przypadku zagrożenia i stanu wojny prezydent przekazuje dowodzenie Naczelnemu Wodzowi, którym może być szef Sztabu Głównego (Generalnego) Sił Zbrojnych Republiki Chorwacji (Glavni stožer Oružanih snaga Republike Hrvatske, GS OS RH), gdyby się okazało, że minister obrony $-\mathrm{z}$ różnych powodów - nie jest $\mathrm{w}$ stanie wykonywać poleceń i rozkazów prezydenta ${ }^{36}$.

System kierowania wojskami Chorwacji oparty jest na wysokim poziomie dyscypliny oraz jednoosobowym dowodzeniu na każdym poziomie ${ }^{37}$. Organ pomocniczy stanowi Centrum Operacyjno-Dowódcze, które ma możliwość samodzielnego kierowania jednostkami wojskowymi stacjonującymi

${ }^{34}$ Ustawa została uchwalona przez parlament chorwacki 19 marca 2002 r., zaś 25 marca jej tekst podano do publicznej wiadomości.

${ }^{35}$ Ustav Republike Hrvatske (pročišćeni tekst), „Narodne novine”, br. 28/2001, Zagreb, 25. travnja 2001, Članak 93 i 99.

${ }^{36}$ Prijedlog Zakona o Obrani s 19. prosinca 2012, 2. Predsjednik Republike Hrvatske i Vrhovni Zapovjednik Oružanih Snaga, Članak 6, s. 6-7; Zakon o obrani, br. 01-081-02-1297/2, Zagreb, 25. ožujka 2002, Članak 3, 7, 10 i 100 .

${ }^{37}$ Ibidem, Članak 102. 
zarówno na terytorium Chorwacji, jak też poza jej granicami. Politycznie parlamentarną kontrolę nad siłami zbrojnymi sprawuje parlament (Sabor).

Prezydentowi pomaga w zarządzaniu systemem obronnym Rada Obrony $^{38}$, której zadaniem jest koordynacja prac wszystkich organów państwa w zakresie przedmiotowym. Rada zajmuje się również: rozpatrywaniem spraw, dotyczących prawidłowego funkcjonowania systemu obrony kraju; opiniowaniem i opracowaniem aktów prawnych, związanych z działalnością sił zbrojnych; planowaniem i wdrażaniem planów modernizacji i rozwoju armii chorwackiej. Ponadto opiniuje propozycje zwiazane z finansowaniem obronności oraz udziałem OS RH w misjach poza granicami kraju. W skład Rady wchodza: prezydent, premier, ministrowie spraw wewnętrznych, obrony, spraw zagranicznych, finansów, szef Sztabu Głównego OS RH, szef Kancelarii Prezydenta, szef Wojskowego Gabinetu Prezydenta, doradcy prezydenta ds. obrony i bezpieczeństwa narodowego ${ }^{39}$. Sesje (obrady) zwołuje prezydent w uzgodnieniu z premierem. W zależności od omawianych problemów, w spotkaniach moga uczestniczyć zaproszeni goście (eksperci). W czasie zagrożenia wojennego Rada może przejąć część obowiązków rządu ${ }^{40}$.

Kolejnym segmentem w kierowaniu systemem obrony jest Ministerstwo Obrony. Stanowi ono centralny urząd władzy wykonawczej republiki chorwackiej, odpowiadajacy za: planowanie i rozwój systemu obrony; koordynację planów obronnych i innych dokumentów planistycznych (przygotowanie państwa na wypadek zagrożenia wojennego lub wystapienia sytuacji kryzysowych); ocenę zagrożeń kryzysowych i wojennych; realizację międzynarodowej współpracy wojskowej, zgodnie z zawartymi

${ }^{38}$ Prijedlog Zakona o Obrani s 19. prosinca 2012, 4. Vijeće za Obranu, Članak 8, s. 8.

${ }^{39}$ Ibidem, Članak 9, s. 8.

${ }^{40}$ Ibidem, Članak 10. 
porozumieniami i umowami; finansowanie sił zbrojnych; kontrolę gotowości sytemu obronnego republiki; opracowanie Strategicznego Przeglądu Obronnego. Ponadto MO RH realizuje zadania z zakresu: organizacji, szkolenia i wyposażenia OS RH; nadzoru nad produkcją oraz sprzedażą broni i sprzętu wojskowego; utrzymania infrastruktury wojskowej; nadzoru i kierowania systemem bezpieczeństwa i ochrony informacji niejawnych; planowania i przygotowania systemu mobilizacyjnego; utrzymania gotowości bojowej oraz organizacji i funkcjonowania systemu alarmowania, ostrzegania i powiadamiania ${ }^{41}$.

Na czele Ministerstwa stoi minister, który jest członkiem rządu i Rady Obrony.

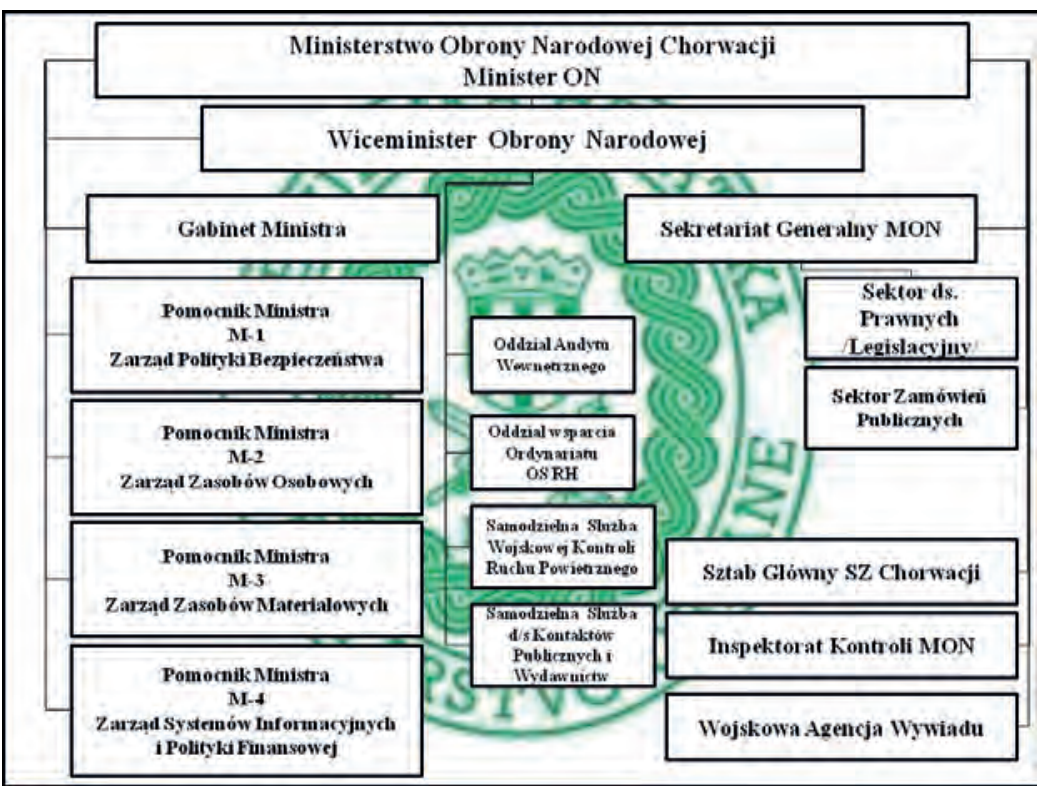

Schemat 1. Struktura organizacyjna Ministerstwa Obrony Chorwacji Źródło: Ministarstvo obrane Republike Hrvatske, http://www.morh.hr/.

${ }^{41}$ Ibidem, 5. Ministarstvo Obrane, Članak 11-15, s. 8-11. 
W czasie pokoju minister kieruje resortem, a w imieniu prezydenta dowodzi Siłami Zbrojnymi. Ministrowi podlegaja wojskowe służby specjalne Chorwacji.

Jeden z poważniejszych problemów wojska i państwa ostatnich lat stanowi budżet na obronność. O ile Chorwatom udało się do 2009 r. utrzymać finansowanie sił zbrojnych (obronności) na poziomie prawie $2 \% \mathrm{PKB}$, to w kolejnych latach nakłady na wojsko diametralnie spadły. W 2011 r. było to 882244 tys. dolarów, co stanowiło 1,42\% PKB. W następnym roku wydano 845543 tys. dolarów (1,3\% PKB). Natomiast w 2013 r. zaplanowano wydatkowanie 824412 tys. dolarów na obronność (około 1,2\% PKB) ${ }^{42}$.

\section{Siły Zbrojne Republiki Chorwacji}

Najważniejszym elementem chorwackiego systemu obronnego są Siły Zbrojne Republiki Chorwacji. Do podstawowych ich zadań należy zaliczyć: ochronę i obronę suwerenności, niezawisłości i niepodległości państwa; udział w operacjach reagowania kryzysowego za granica; uczestnictwo $\mathrm{w}$ budowie środków zaufania i bezpieczeństwa oraz pomoc dla instytucji cywilnych w kraju w sytuacjach kryzysowych ${ }^{43}$.

Współcześnie prawdopodobieństwo konwencjonalnego ataku na Republikę Chorwacji jest bardzo niskie, natomiast, jak wynika z dokumentów doktrynalnych, terytorium państwa może być obiektem zagrożeń o charakterze asymetrycznym. Aby wykonać podstawową konstytucyjną misję, OS RH

${ }^{42}$ Godišnja razmjena informacija o obrambenom planiranju 2012, Zagreb 2012, s. 25-32.

${ }^{43}$ Dugoročni plana razvoja OS RH 2006-2015, Zagreb 2006, s. 7. 
muszą zachować możliwość użycia potencjału militarnego na takim poziomie, by skutecznie odeprzeć wroga.

Siły Zbrojne Chorwacji stanowia podstawowy komponent systemu obrony państwa. Składają się z trzech rodzajów wojsk: Wojsk Ląowych (Hrvatska kopnena vojska, HKoV), Sił Powietrznych i Obrony Przeciwlotniczej (Hrvatsko ratno zrakoplovstvo i protuzračna obrana, HRZ i PZO) oraz Marynarki Wojennej (Hrvatska ratna mornarica, HRM).

\section{Sztab Główny OS RH}

$\mathrm{Na}$ czele systemu dowodzenia siłami zbrojnymi stoi szef Sztabu Głównego OS RH. Sztab Główny jest komponentem MO $\mathrm{RH}$, a jego szef jest bezpośrednim podwładnym ministra obrony. Szef GS OS RH wchodzi w skład Rady Obrony i w czasie pokoju dowodzi wszystkimi jednostkami sił zbrojnych. Jest powoływany na pięcioletnią kadencję $e^{44}$, którą może sprawować tylko dwukrotnie. Podczas wojny może w wyjątkowych sytuacjach (o których już wspomniano) przejać bezpośrednie dowodzenie od Zwierzchnika Sił Zbrojnych i Naczelnego Dowódcy, czyli Prezydenta Republiki. Szef Sztabu i Sztab odpowiadaja za dowodzenie, przygotowanie i funkcjonowanie sił zbrojnych, zgodnie z decyzjami prezydenta i ministra obrony oraz aktami prawnymi regulującymi działalność systemu obronnego państwa. A ponadto do ich zadań należy zaliczyć: opracowywanie planów użycia sił zbrojnych oraz uczestnictwo w pracach nad strategia obrony państwa; przygotowywanie długoterminowych koncepcji rozwoju sił zbrojnych; planowanie, organizowanie i prowadzenie

${ }^{44}$ Szef Sztabu może być mianowany na czteroletnią kadencję, która w wyjątkowej sytuacji może być przedłużona o rok, Prijedlog Zakona o Obrani..., Članak 14, s. 10. 
szkoleń na wszystkich szczeblach sił zbrojnych ${ }^{45}$; kierowanie przygotowaniami komponentu chorwackiego do działań w ramach sojuszniczych sił odpowiedzi i grup bojowych; branie udziału w projektach na rzecz umacniania sojuszniczych zdolności obronnych, realizowanych w ramach NATO i UE; nadzorowanie, planowanie i organizacja systemu wsparcia logistycznego sił zbrojnych; organizacja bezpieczeństwa i działań kontrwywiadowczych w siłach zbrojnych ${ }^{46}$.

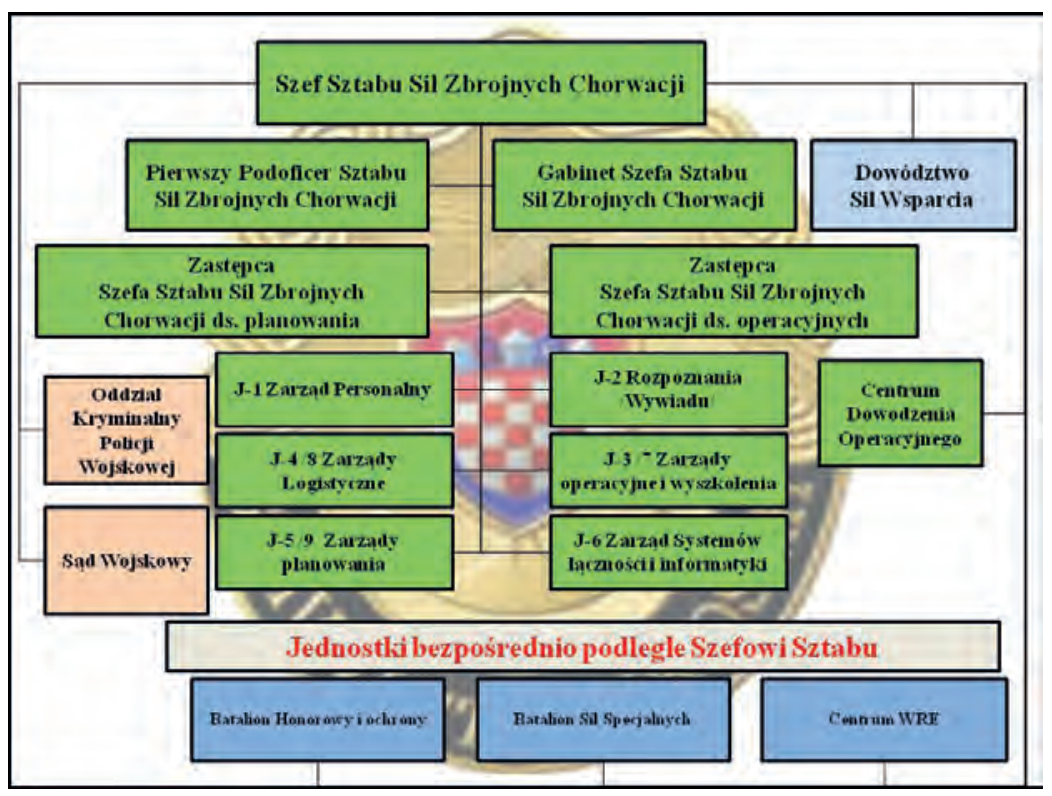

Schemat 2. Struktura organizacyjna Sztabu Głównego Sił Zbrojnych Chorwacji

Źródło: http://www.osrh.hr/prikaz_hr.asp?g]o@=775\&Uvf]=4.

${ }^{45}$ Planowanie, organizacja i szkolenie odbywają się w poszczególnych centrach i ośrodkach podległych rodzajom wojsk. Sztab Główny określa cele, ramy, metodę i harmonogram. Szczegółowe planowanie i praktyczne wykonanie pozostawiono w gestii specjalistycznych ośrodków.

${ }^{46}$ Ibidem, Članak 15, s. 11. 
Organizacyjnie, oprócz trzech rodzajów wojsk (lądowych, sił powietrznych i obrony przeciwlotniczej oraz morskich), podlegaja mu przysztabowe (samodzielne) jednostki (patrz: schemat 2).

Wojska Lądowe, według najnowszych danych, liczą około 9,5 tys. żołnierzy ${ }^{47}$ (docelowo około 10,3 tys.). Na uzbrojeniu posiadaja: 72 czołgi $^{48}$ (wersja M-84A4M) oraz 177 transporterów opancerzonych i bojowych wozów piechoty (typu: BVP M-80, POLO M-83 Patria), a ponadto prawie 600 zestawów artylerii przeciwlotniczej (w tym także rakietowych), prawie 500 zestawów artyleryjsko-rakietowych i ponad 500 wyrzutni przeciwpancernych pocisków kierowanych (typu: Malutka, Fagot, Metys). Armia chorwacka posiada także prawie 2 tys. różnego rodzaju pojazdów.

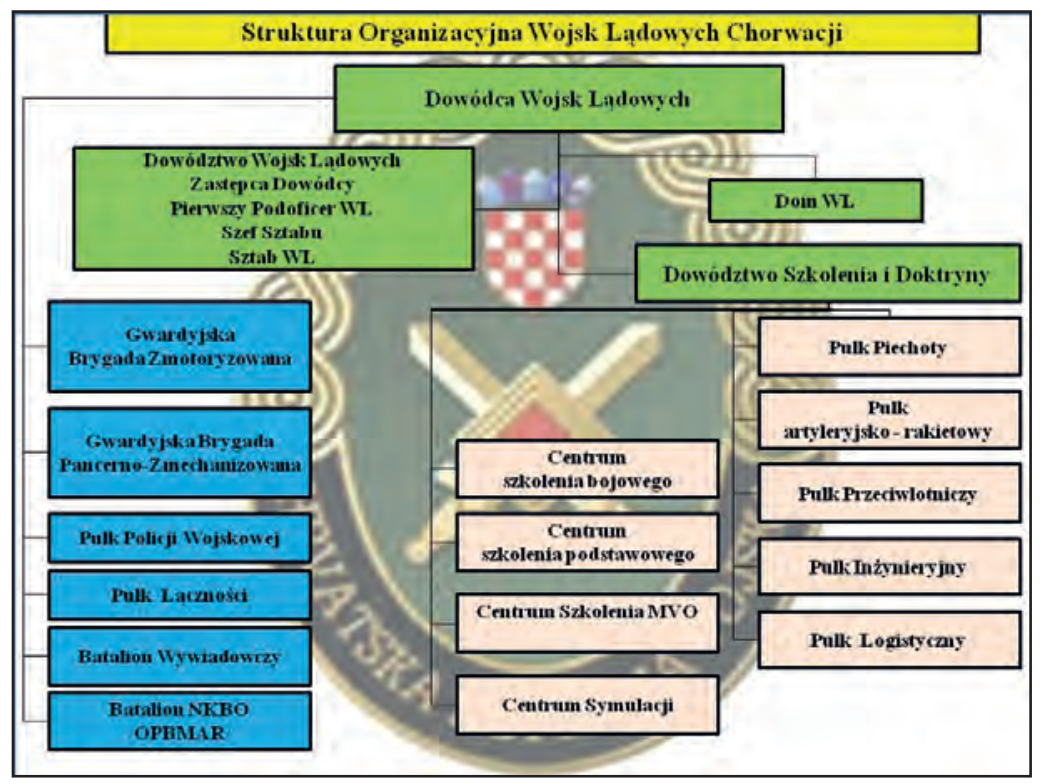

Schemat 3. Struktura organizacyjna Wojsk Lądowych Chorwacji Źródło: http://www.osrh.hr/prikaz_hr.asp?g]o@=776\&Uvf]=4.

${ }^{47}$ Oružane snage Republike Hrvatske. Općenito o OSRH, http://www. osrh.hr/prikaz_hr.asp?g]o@=774\&Uvf]=4 (dostęp 22 III 2013). 
Trzon Wojsk Lądowych tworza dwie w pełni zawodowe brygady i jednostki wsparcia. Na uwagę zasługuje duża liczba jednostek specjalnych typu policyjnego i wywiadowczego $^{49}$. Głównym ich zadaniem jest obrona suwerenności i integralności państwa chorwackiego. Realizuje się to poprzez utrzymanie stałej gotowości do działań oraz wysokiego poziomu wyszkolenia wojsk ${ }^{50}$. Do innych zadań Wojsk Lądowych Republiki Chorwacji można zaliczyć: rozwój i utrzymanie wysokiego stopnia gotowości bojowej do prowadzenia działań na terytorium Chorwacji i poza jej granicami, a także utrzymywanie umiejętności prowadzenia operacji bojowych w środowisku zagrożeń asymetrycznych; udział $\mathrm{w}$ operacjach międzynarodowych, przygotowanie i rozwijanie zdolności do zwiększania interoperacyjności działań z państwami sojuszniczymi; przygotowanie infrastruktury do wsparcia sił sojuszniczych działajacych z terytorium Chorwacji; współdziałanie w budowaniu środków zaufania i tworzeniu bezpiecznego środowiska w odniesieniu do regionu i Europy; udział we wsparciu przedsięwzięć władz cywilnych, zwłaszcza w ramach przeciwdziałania sytuacjom kryzysów, klęsk i katastrof ${ }^{51}$.

${ }^{48}$ Chorwaci posiadają także 192 czołgi typu T-55. Są one zakonserwowane i zmagazynowane, Dugoročni plana razvoja..., s. 23.

${ }^{49}$ Każda z jednostek OS RH posiada integralny pododdział policji wojskowej (oprócz pułku policji wojskowej). Ponadto na szczeblu związków ogólnowojskowych znajdują się kompanie i plutony rozpoznawcze. Dodatkowo w strukturach podległych szefowi Sztabu istnieje Batalion Sił Specjalnych (w wojskach lądowych natomiast Batalion Wywiadowczy). Należy zauważyć, że w strukturze organizacyjnej Sił Zbrojnych Chorwacji występuje dużo oddziałów i pododdziałów wywiadowczych i sił specjalnych.

${ }^{50}$ Ibidem, s. 20.

${ }^{51}$ Ibidem. 


\section{Siły Powietrzne i Obrony Powietrznej}

Siły Powietrzne i Obrony Powietrznej powstały w grudniu 1991 r. Podczas działań wojennych 1991-1995 Chorwatom udało się pozyskać lub zdobyć kilkadziesiąt maszyn, w tym kilka bojowych. Część z nich nadal stanowi wyposażenie HRZ i PZO. Trzonem sił powietrznych jest eskadra bojowa na samolotach MiG-21, które - pomimo modernizacji - są stopniowo wycofywane ze służby. Chorwacja potrzebuje około 12 wielozadaniowych maszyn, jednak ze względu na brak środków finansowych zakup nowych maszyn został przełożony na późniejszy termin.

Zadaniem HRZ i PZO jest utrzymanie jak najwyższego poziomu gotowości $\mathrm{w}$ celu powstrzymania agresji przeciwko Republice Chorwacji, a także: nadzór i ochrona (obrona) przestrzeni powietrznej kraju; rozwijanie zdolności do uczestnictwa we wspólnych działaniach z sojusznikami; udział w międzynarodowych wojskowych operacjach pokojowych; przygotowanie i utrzymanie zdolności do prowadzenia działań w środowisku asymetrycznych zagrożeń; przygotowanie i utrzymanie infrastruktury, umożliwiającej działania sił NATO z terytorium Chorwacji; uczestnictwo w przedsięwzięciach z zakresu kontroli zbrojeń i budowy środków zaufania i bezpieczeństwa; udział w operacjach poszukiwawczo-ratowniczych na obszarze własnego kraju, jak również poza jego granicami ${ }^{52}$. Na wyposażeniu znajduje się 45 samolotów, w tym 10 bojowych - zmodernizowanych typu: MiG-21 BISD i UM (4) - oraz 32 śmigłowce ${ }^{53}$. Obecnie w chorwackich siłach powietrznych pełni służbę lub pracuje około 1,7 tys. osób ${ }^{54}$.

${ }^{52}$ Ibidem, s. 27.

${ }^{53}$ Ibidem, s. 30.

${ }^{54}$ Około 1,4 tys. żołnierzy oraz ponad 240 pracowników cywilnych, Oružane snage Republike Hrvatske. Općenito o... 
Chorwacja nie posiada integralnych bojowych systemów artyleryjsko-rakietowych wchodzacych w skład Sił Powietrznych i Obrony Powietrznej kraju. Osłonę przeciwlotniczą moga stanowić tylko zestawy będące na wyposażeniu Wojsk Lądowych (w przeważającej ilości sa to kompleksy do niszczenia środków napadu powietrznego na małych odległościach).

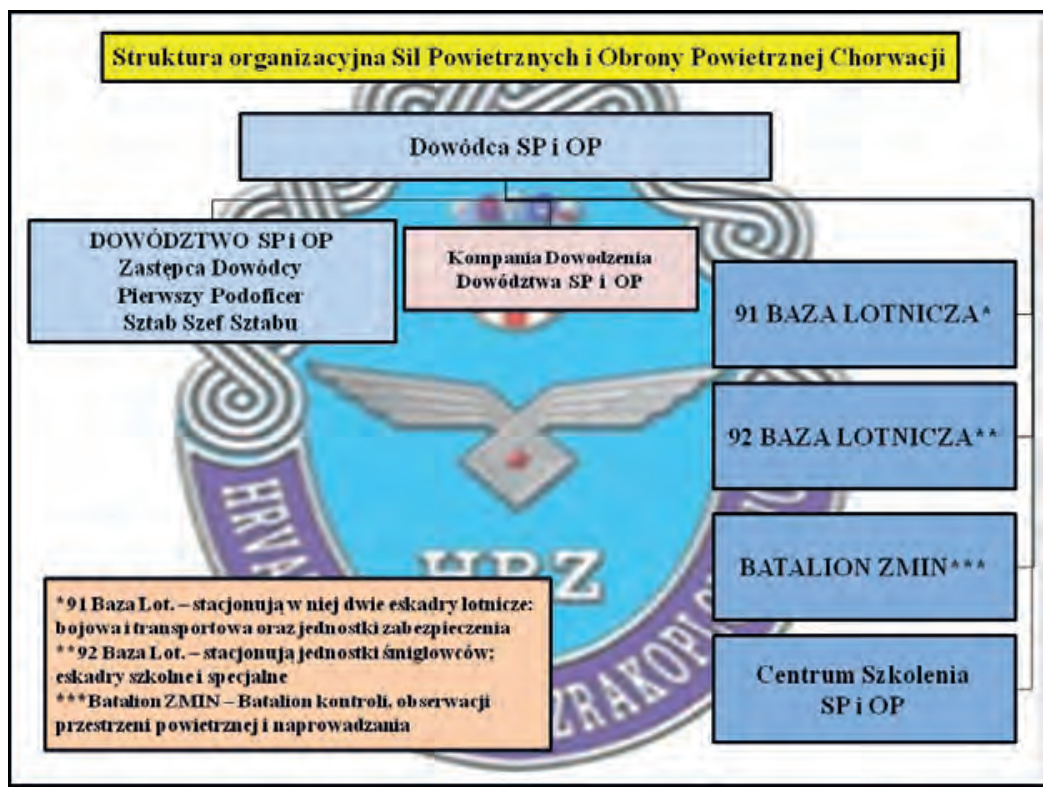

Schemat 4. Struktura organizacyjna Sił Powietrznych i Obrony

Powietrznej Chorwacji

Źródło: http://www.osrh.hr/prikaz_hr.asp?g]o@=777\&Uvf]=4/. 


\section{Marynarka Wojenna}

Marynarka Wojenna Chorwacji, podobnie jak pozostałe rodzaje Sił Zbrojnych, powstała w drugiej połowie $1991 \mathrm{r}$. Pierwsze jednostki bojowe zostały przejęte od federalnej Marynarki Wojennej. Pomimo wycofania większości sił morskich Jugosławii do baz w Czarnogórze, Chorwatom udało się zdobyć kilkanaście okrętów bojowych. Ponadto zajęli także całą infrastrukturę morska, pozostawiona na ich terytorium przez wycofujace się siły federalne. Przejęli także nieukończone jednostki, które znajdowały się w stoczniach federalnych sił morskich Jugosławii. Część z nich rozpoczęła następnie służbę w HRM.

Do głównych zadań chorwackiej Marynarki Wojennej należy zaliczyć:

- utrzymanie wysokiego poziomu gotowości bojowej $\mathrm{w}$ celu powstrzymania ewentualnej agresji przeciwko Republice Chorwacji;

- sprawowanie nadzoru i ochrony obszarów morskich i podmorskich szelfu kontynentalnego;

- rozwijanie i utrzymywanie zdolności operacyjnych do uczestnictwa we wspólnych działaniach Sojuszu;

- utrzymywanie i rozwijanie zdolności bojowych jednostek piechoty morskiej do prowadzenia działań desantowych na terytorium Chorwacji i poza jej granicami;

- przygotowanie i utrzymanie zdolności do prowadzenia działań w środowisku asymetrycznych zagrożeń (na morzu), udział w operacjach poszukiwawczo-ratowniczych;

- przygotowanie i utrzymanie infrastruktury, umożliwiającej działania sił morskich NATO z wybrzeży Chorwacji;

- uczestnictwo $\mathrm{w}$ przedsięwzięciach $\mathrm{z}$ zakresu kontroli zbrojeń i budowy środków zaufania i bezpieczeństwa; 
- udział w operacjach poszukiwawczo-ratowniczych na mo$\mathrm{rzu}^{55}$.

Ponadto zadaniem Dowództwa Marynarki Wojennej jest aktywne wsparcie procesu rozwoju i doskonalenia kadry HRM we wszystkich obszarach działalności zawodowej.

Chorwacka Marynarka Wojenna składa się z pięciu zasadniczych komponentów: sił morskich, zabezpieczenia i wsparcia, artyleryjsko-rakietowych jednostek obrony wybrzeża, jednostki piechoty morskiej i Straży Przybrzeżnej.

W Marynarce Wojennej pełni służbę ponad 1,6 tys. marynarzy i oficerów ${ }^{56}$. Jej trzon stanowi Flotylla, w skład której wchodzą główne siły bojowe, złożone z: pięciu okrętów rakietowych ${ }^{57}$, jednego trałowca, pięciu okrętów desantowych (w tym dwóch stawiaczy min) i kilkunastu jednostek pomocniczych. W skład Straży Obrony Wybrzeża wchodzą cztery okręty patrolowe i pięć jednostek pomocniczych $^{58}$. Na komponent sił artyleryjsko-rakietowej obrony brzegowej składaja się trzy mobilne wyrzutnie rakiet ziemia-woda typu RBS-15B (zapas rakiet: 47) oraz 36 dział artylerii nadbrzeżnej różnych kalibrów (będących pozostałością po systemie obrony wybrzeża z okresu Jugosławii) ${ }^{59}$. Komponent jest wsparty czterema zestawami radarów typu Enhaced Peregrine ${ }^{60}$.

${ }^{55}$ Oružane Snage Republike Hrvatske. HRM - Oćenito, http://www. osrh.hr/prikaz_hr.asp?g]o@=770\&Uvf]=4 (dostęp 20 III 2013).

${ }^{56}$ Ponad 200 osób stanowi personel cywilny, Oružane snage Republike Hrvatske. Općenito o...

${ }^{57} \mathrm{~W}$ nomenklaturze chorwackiej jednostki te są nazywane kanonierkami rakietowymi.

${ }^{58}$ Oružane Snage Republike Hrvatske. HRM...

${ }^{59}$ Dugoročni plana razvoja..., s. 27.

${ }^{60}$ Chorwaci posiadaja ponadto jeszcze trzy zestawy radarowe starszej generacji, ibidem. 
Marynarka Wojenna Chorwacji wymaga gruntownego doposażenia i wymiany jednostek pływających, zwłaszcza zakupu nowoczesnych okrętów bojowych. Konieczne są także inwestycje w infrastrukturę techniczna, chociaż wydaje się ona imponujaca.

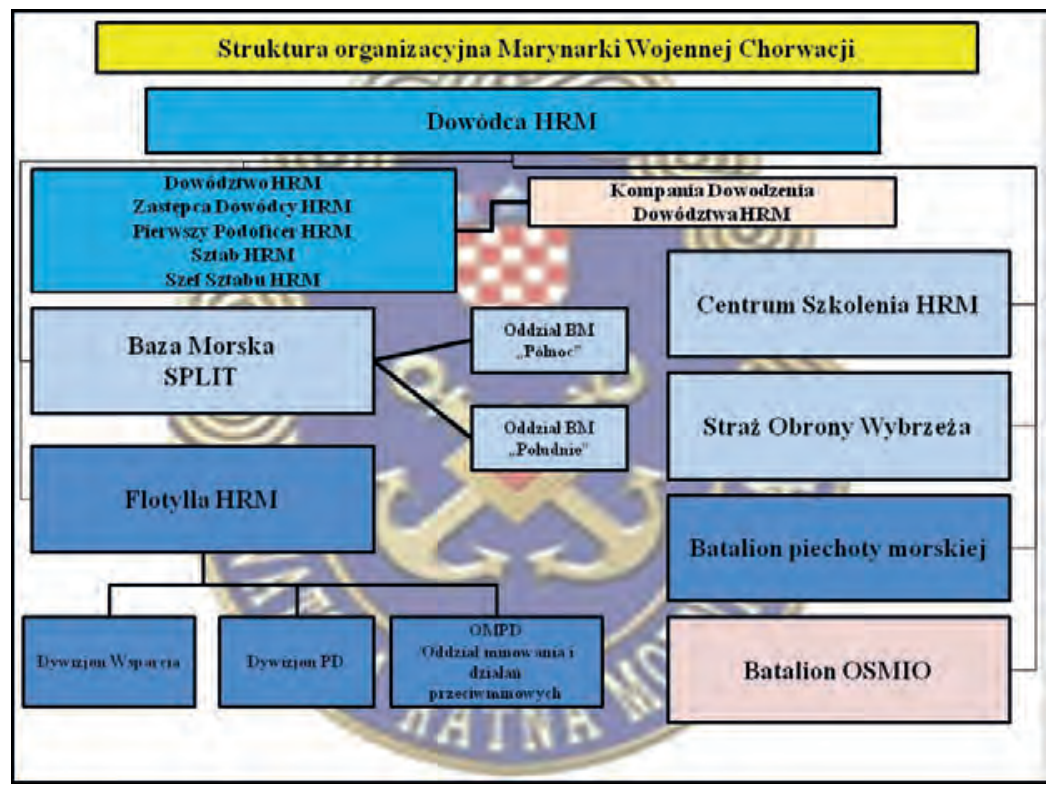

Schemat 5. Struktura organizacyjna Marynarki Wojennej Chorwacji Źródło: http://www.osrh.hr/prikaz_hr.asp?g]o@=777\&Uvf]=4/.

Dowództwo Marynarki Wojennej zachowało szereg morskich obiektów wojskowych, w tym schrony dla okrętów wojennych (12 - rozmieszczonych na wyspach adriatyckich) oraz porty wojenne (osiem - w tym największe, w których na stałe bazuja jednostki HRM: Split, Pula, Ploče, Šibenik). Część z nich zostanie przygotowana do przyjęcia i zabezpieczenia działań dla sił morskich NATO. 


\section{Dowództwo Sił Wsparcia}

Oprócz trzech rodzajów sił zbrojnych w ramach $\mathrm{OS} \mathrm{RH}$ funkcjonuje również Dowództwo Sił Wsparcia (Zapovjedništvo za potporu, ZzP) oraz Centrum Kształcenia „Petar Zrinski”, które tworza, oprócz Akademii Wojskowej, szkoły i centra szkolenia szczebla centralnego, odpowiadające za kształcenie i szkolenie personelu wojskowego i cywilnego Sił Zbrojnych Republiki Chorwacji.

Dowództwo Sił Wsparcia - podporządkowane jest szefowi Sztabu GS OS RH i stanowi centralny organ odpowiedzialny za kompleksowe zabezpieczenie logistyczne armii chorwackiej. Dowództwo powstało w 2007 r. po reorganizacji syste$\mathrm{mu}$ logistycznego OS $\mathrm{RH}^{61}$. Zatrudnionych $\mathrm{w}$ strukturach Sił Wsparcia jest 2579 żołnierzy, urzędników i pracowników państwowych ${ }^{62}$.

${ }^{61}$ Rozwiązanie zastosowane w Chorwacji jest podobne do tych, które wcześniej w swoich siłach zbrojnych zastosowali Niemcy, Czesi i Słowacy. Scentralizowanie usług logistycznych ma pomóc we właściwym i sprawnym zabezpieczeniu logistycznym w okresie pokoju, jak i w czasie prowadzenia działań, np. misji poza granicami kraju.

${ }^{62}$ Urzędnicy i pracownicy państwowi - to grupa zatrudnionych w strukturach MO RH (w Polsce sa to pracownicy cywilni wojska). Chorwaci wyróżniaja w ramach tej grupy: pracowników technicznych i obsługi, urzędników zatrudnionych $\mathrm{w}$ administracji, sektorze IT oraz komórkach analitycznych ministerstwa, dowództw i rodzajów wojsk. W strukturach Sił Wsparcia jest zatrudnionych 1154 urzędników i pracowników, Oružane snage Republike Hrvatske. Općenito o... 


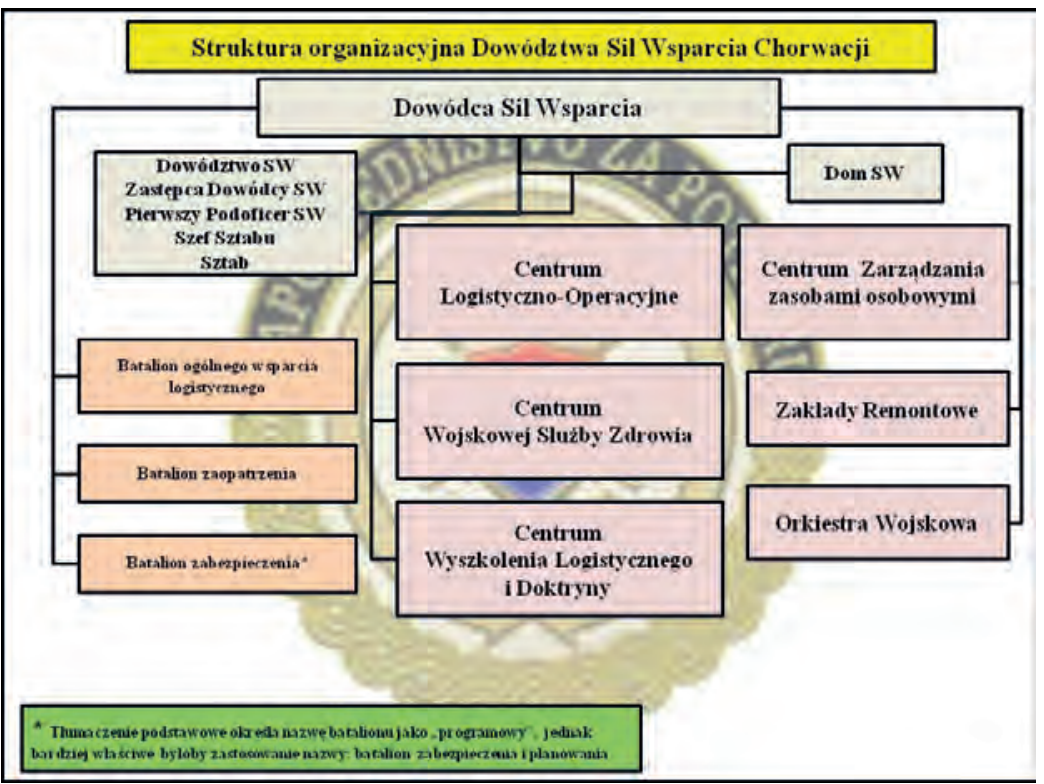

Schemat 6. Struktura organizacyjna Dowództwa Sił Wsparcia Chorwacji Źródło: http://www.osrh.hr/prikaz_hr.asp?g]o@=777\&Uvf]=4/.

Siły Wsparcia maja za zadanie: zabezpieczenie i wsparcie logistyczne i medyczne wszystkich rodzajów wojsk armii chorwackiej, zarówno w czasie pokoju, jak i wojny; rozwijanie zdolności logistycznych i medycznych; podwyższanie stopnia wyszkolenia w zakresie umiejętności zabezpieczenia logistycznego i medycznego jednostek oraz personelu Sił Wsparcia. Ponadto mają: być w gotowości do zabezpieczenia operacji pokojowych, humanitarnych i innych misji poza granicami kraju (zarówno w odniesieniu do własnych wojsk, jak i prowadzenia takich operacji samodzielnie); utrzymywać w sprawności obiekty infrastruktury logistycznej i medycznej OS RH; przechowywać i zabezpieczać zasoby logistyczne i medyczne, umożliwiające realizację szkoleniowych 
i bojowych zadań przez OS RH; wykonywać na najwyższym technicznym poziomie obsługę remontów całego sprzętu uzbrojenia i wyposażenia armii ${ }^{63}$. Jednocześnie do zadań związanych z zobowiązaniami sojuszniczymi można zaliczyć: przygotowanie i utrzymanie infrastruktury logistycznej dla sił sojuszniczych; udział w działaniach logistycznych na rzecz NATO; udział w szkoleniu, treningach i operacjach Sojuszu ${ }^{64}$.

Chorwacka logistyka, według założeń Długoterminowego Planu, ma przed sobą szereg zadań, przede wszystkim związanych z przebudową infrastruktury (dotyczy to składów: Doljani, Slunj, Trbounje i Velika Buna) oraz odnowieniem zapasów. Chorwaci będą też musieli uporać się z przygotowaniem obiektów logistycznych dla sił Sojuszu ${ }^{65}$. Część z nich powstanie w oparciu o istniejące urządzenia, użytkowane przez armię chorwacka, inne natomiast należy zbudować od podstaw. W kosztach tych inwestycji będzie wprawdzie partycypować NATO, lecz znaczna część wydatków zostanie pokryta przez stronę chorwacka. W ramach rozwoju i podnoszenia efektywności zabezpieczenia medycznego Chorwaci planuja wprowadzenia dwóch projektów - ROLE-1 i ROLE-2, które maja doprowadzić do stworzenia zespołów medycznych interoperacyjnych, mogących działać o każdym czasie i w każdym miejscu - zarówno na terytorium kraju, jak i poza jego granicami ${ }^{66}$.

$$
* * *
$$

${ }^{63}$ Dugoročni plana razvoja..., s. 32.

${ }^{64}$ Oružane Snage Republike Hrvatske. Zapovjedništvo za potporu - Općenito, http://www.osrh.hr/prikaz_hr.asp?g]o@=772\&Uvf]=4 (dostęp 20 III 2013).

${ }^{65}$ Dugoročni plana razvoja..., s. 31.

${ }^{66}$ Ibidem. 
Armia chorwacka, powstała przed ponad 20 laty, to obecnie stosunkowo nowoczesny komponent polityki bezpieczeństwa Chorwacji. Należy zgodzić się ze stwierdzeniem, iż stanowi najważniejszy podsystem systemu obronnego państwa. Stosunkowo nieliczne chorwackie siły zbrojne, będące obecnie w ostatniej fazie reorganizacji, sa w stanie zrealizować większość zadań, jakie wynikaja z dokumentów doktrynalnych i aktów prawnych warunkujących istnienie państwa, ale nie zdołałyby sprostać agresji większego państwa. Jednak członkostwo w NATO gwarantuje Chorwacji pomoc ze strony pozostałych państw, zgodnie z art. 5 Traktatu Północnoatlantyckiego. Chorwaci ciagle rozwijają swoje zdolności bojowe i logistyczne. Jak większość krajów modernizujących siły zbrojne, także i oni napotykaja sporo problemów. Z pewnościa jednym z najistotniejszych, mającym duży wpływ na tempo realizacji reform, jest brak środków finansowych. Tymczasem koszty modernizacji sprzętu, zwłaszcza zakupu nowych systemów uzbrojenia (np. przeciwlotniczych, samolotów, okrętów bojowych, systemów teleinformatycznych i radarowych itd.) przekraczaja możliwości budżetu państwa. Chorwaci, dotknięci skutkami kryzysu gospodarczego, starają się jednak $\mathrm{w}$ minimalnym zakresie realizować zapisy zawarte w Długoterminowym Planie Rozwoju OS RH, przyjętym w 2006 r. Można się spodziewać, że część zadań będzie musiała jeszcze poczekać na realizację. Część natomiast została już wykonana lub wkrótce zostanie. Udało im się także zmniejszyć liczebność sił zbrojnych oraz podwyższyć kwalifikacje żołnierzy i pracowników wojska. Wzrostowi poziomu wyszkolenia służy, realizowany od kilkudziesięciu miesięcy, projekt „Cadet”. Ponadto położono też nacisk na stałe szkolenie rezerw osobowych, aby armia dysponowała stanem prawie 40 tys. Dzięki temu w wypadku ogłoszenia 
zagrożenia wojennego można będzie zwiększyć liczebność sił zbrojnych do prawie 60 tys. dobrze wyszkolonych oraz uzbrojonych oficerów i żołnierzy ${ }^{67}$.

Warto też zauważyć, że kierownictwo Ministerstwa Obrony oraz Dowództwo Sił Zbrojnych przywiązują znaczną wagę do współpracy cywilno-wojskowej, a szczególnie do wsparcia władz administracyjnych i samorząowych w zakresie reagowania kryzysowego. Obok przedsięwzięć szkoleniowych i treningowych, jednostki wojskowe (zwłaszcza siły powietrzne) aktywnie uczestniczą w akcjach pomocowych, związanych z likwidacją skutków katastrof technicznych i klęsk żywiołowych. Podsystem militarny państwa (którego głównym komponentem są Siły Zbrojne) jest ściśle związany z podsystemem pozamilitarnym (jednym z zasadniczych elementów jego jest Obrona Cywilna). Zadania obu podsystemów w zakresie powszechnej obrony sa sprecyzowane i umożliwiają wykorzystanie obu komponentów w okresie wojny i pokoju.

Dużym mankamentem współczesnego systemu bezpieczeństwa państwa jest brak aktualnych dokumentów doktrynalnych, zwłaszcza w odniesieniu do nowej Strategii Bezpieczeństwa Narodowego, Doktryny Wojennej (lub Strategii Obrony) oraz niezakończonego Strategicznego Przeglądu Obronnego. Poprawiane oraz uzupełniane dokumenty, co prawda, umożliwiaja funkcjonowanie systemu obrony państwa, jednak wydaje się niezbędne, aby Chorwacja precyzyjniej określiła swoje stanowisko wobec członkostwa w NATO oraz UE. Akces do Unii zobowiązuje przecież ją do wypracowania wspólnotowych kierunków polityki zagranicznej i bezpieczeństwa, nie tylko w odniesieniu do Bałkanów, ale także do Europy. Chorwacja zrealizowała

${ }^{67}$ Ibidem, s. 36. 
w ramach przygotowań akcesyjnych praktycznie wszystkie wymogi, dotyczące tego działu negocjacji, jednak kwestie doktrynalne, które nadal pozostaja niedopracowane, powinny zostać ostatecznie rozwiązane i przybrać formę określonych aktów wykonawczych. Szczególnie istotne wydaje się przygotowanie Strategii Bezpieczeństwa Narodowego oraz nowego SPO, które pozwoliłyby na sformułowanie celów działania, jednocześnie kończąc reorganizację podsystemu militarnego w nowej rzeczywistości geopolitycznej, czyli po wejściu Chorwacji do UE. 